\title{
Effect of Nitrogen Application through Urea and Azolla on Growth and Biological Yield of Rice (Oryza sativa L.) in Acidic Soil of Meghalaya
}

\author{
Shubham Singh, Sanjay Swami* and G.N. Gurjar
}

School of Natural Resource Management, College of Post Graduate Studies, Central Agricultural University, Umiam-793103, Meghalaya, India

*Corresponding author

\begin{tabular}{|c|c|}
\hline & A B S T R A C T \\
\hline & \multirow{9}{*}{ 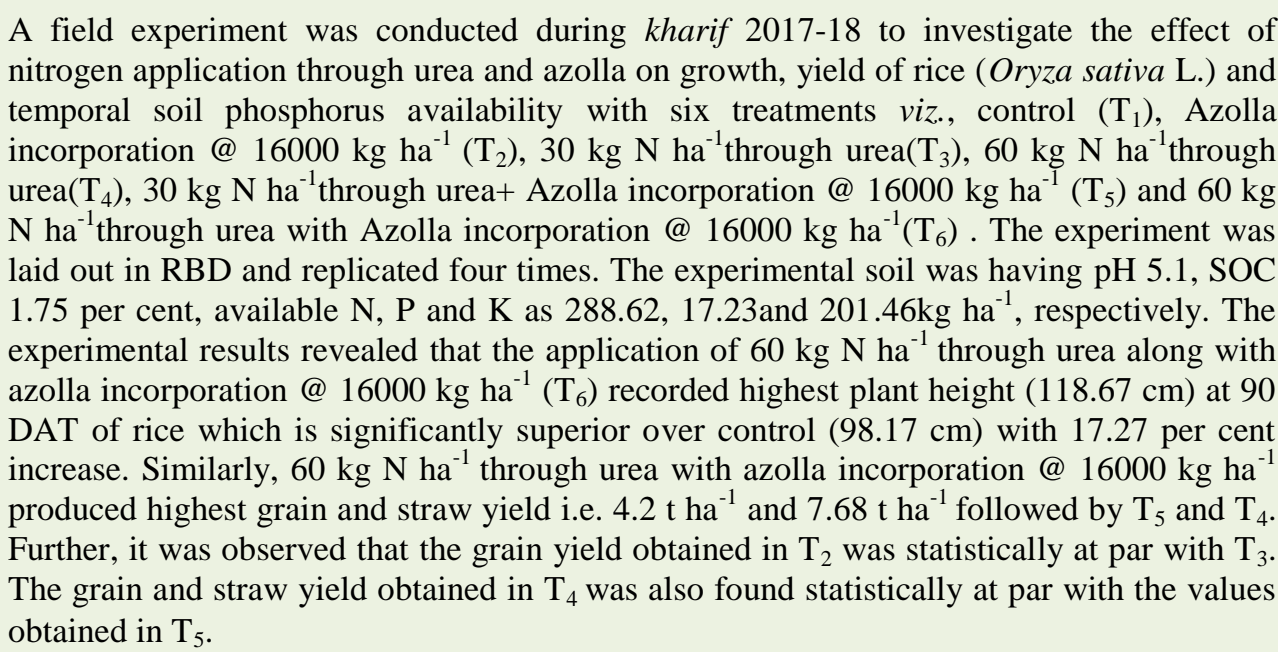 } \\
\hline & \\
\hline & \\
\hline $\begin{array}{l}\text { Chemical fertilizers, } \\
\text { Integrated nutrient }\end{array}$ & \\
\hline $\begin{array}{l}\text { management, Rice, } \\
\text { Yield, Acidic soil }\end{array}$ & \\
\hline Article Info & \\
\hline $\begin{array}{l}\text { Accepted: } \\
\text { 24 June } 2018\end{array}$ & \\
\hline Available Onli & \\
\hline & \\
\hline
\end{tabular}

\section{Introduction}

Rice is the most widely consumed staple food for a large part of world's human population, especially in Asia. It is the agricultural commodity with the third highest worldwide production of 741.5 million tones in 2014 (FAOSTAT, 2014).In India, it has total production of 106.5 Mt whereas in Meghalaya it is limited to 2.8 lakh tones (DES, 2015). The food demand is on the increase, the factor productivity and rate of response of crops to applied fertilizers under intensive farming conditions are continuously declining with every passing year. The energy crisis and high fertilizer costs have created considerable concern and the use of organic materials as sources of plant nutrients for lowland rice.

The success of rice production depends mostly on an efficient and economic supply of $\mathrm{N}$ apart from irrigation. The use efficiency of $\mathrm{N}$ from fertiliser sources in lowland rice is notoriously low around 30 to 50 per cent, 
because of its loss from soils through various chemical and biochemical processes. It has, therefore, become necessary to look for alternative renewable resources to meet at least a part of the $\mathrm{N}$ demand of rice crops. $\mathrm{N}$ fixing blue-green algae (BGA) or cyanobacteria and Azolla, have been shown to be the most important in maintaining and improving the productivity of rice fields (Raja et al., 2012). Azolla is a free-floating water fern that floats in the water and fixes atmospheric nitrogen because of its association with the nitrogen fixing cyanobacterium Anabaena. It has also been reported in literature that an Azolla-Anabena system is ideal for the cultivation of rice under tropical conditions because of its ability to fix atmospheric nitrogen and capacity to multiply at faster rates. Keeping these facts in view, the present investigation was carried out to study the effect of nitrogen application through urea and azolla incorporation on growth and yield of rice (Oryza sativa L.) in acidic soil of Meghalaya.

\section{Materials and Methods}

The experiment was conducted at Research Farm of the College of Post-Graduate Studies (CPGS), Umiam, Ri-Bhoi district of Meghalaya located at $91^{0} 18^{\prime}$ to $92^{0} 18^{\prime} \mathrm{E}$ longitude and $25^{\circ} 40^{\prime}$ to $26^{\circ} 20^{\prime} \mathrm{N}$ latitude with an altitude of $950 \mathrm{~m}$ above the mean sea level during kharif season of 2017. The experimental soil was having $\mathrm{pH} 5.1$, SOC 1.75 per cent, available $\mathrm{N}, \mathrm{P}$ and $\mathrm{K}$ as 288.62 , 17.23 and $201.46 \mathrm{~kg} \mathrm{ha}^{-1}$, respectively. The field experiment was conducted in Randomized Block Design (RBD) having six treatments and four replications viz., control $\left(\mathrm{T}_{1}\right)$, Azolla incorporation @ $16000 \mathrm{~kg} \mathrm{ha}^{-1}$ $\left(\mathrm{T}_{2}\right), 30 \mathrm{~kg} \mathrm{~N} \mathrm{ha}{ }^{-1}$ through urea $\left(\mathrm{T}_{3}\right), 60 \mathrm{~kg} \mathrm{~N}$ $\mathrm{ha}^{-1}$ through urea $\left(\mathrm{T}_{4}\right), 30 \mathrm{~kg} \mathrm{~N} \mathrm{ha}{ }^{-1}$ through urea + Azolla incorporation @ $16000 \mathrm{~kg} \mathrm{ha}^{-1}$ $\left(\mathrm{T}_{5}\right)$ and $60 \mathrm{~kg} \mathrm{~N} \mathrm{ha}{ }^{-1}$ through urea with Azolla incorporation@16000 kg ha ${ }^{-1}\left(\mathrm{~T}_{6}\right)$. All the agronomic practices were followed for raising paddy crop. The nutrient content of $\mathrm{N}$, $\mathrm{P}$ and $\mathrm{K}$ in azolla was $4.2,0.6$ and 1.9 per cent, respectively on dry weight basis.

Plant height was measured from ground level to the topmost node of the plant from five representative hills of each plot. The average height of plants was expressed in $\mathrm{cm}$. The data recorded at 30, 60, 90 days after transplanting and at maturity. Grain, straw and biological yield of rice were recorded after the harvest of the crop when optimum moisture content was achieved and expressed in tha ${ }^{-1}$. Harvest index was calculated by dividing the economic yield (grain) by biological yield (grain + straw) as suggested by Donald (1976). The data recorded for various parameters were analysed statistically by following procedure of Gomez and Gomez (1984).

\section{Results and Discussion}

\section{Plant height (cm)}

The plant height $(\mathrm{cm})$ of rice under various treatments was recorded at four time intervals of crop growth i.e. 30, 60, 90 days after transplanting and at maturity (Table 1). The significant variations were recorded in plant height due to the treatment combinations at each time interval i.e. 30, 60, 90 DAT and at maturity. The application of $60 \mathrm{~kg} \mathrm{~N}$ $\mathrm{ha}^{-1}$ through urea along with azolla incorporation@16000 kg ha ${ }^{-1}\left(\mathrm{~T}_{6}\right)$ recorded highest plant height $(118.67 \mathrm{~cm})$ at 90 DAT of rice which is significantly superior over control $(98.17 \mathrm{~cm})$ with 17.27 per cent increase. The plant height also increased with $30 \mathrm{~kg} \mathrm{~N} \mathrm{ha}{ }^{-1}$ through urea + azolla incorporation@16000 kg ha ${ }^{-1}\left(\mathrm{~T}_{5}\right)$ over the sole application of $30 \mathrm{~kg} \mathrm{~N}^{-1}$ through urea $\left(\mathrm{T}_{3}\right)$ by 8.95 per cent. Similarly, the plant height also increased in $\mathrm{T}_{6}\left(60 \mathrm{~kg} \mathrm{~N} \mathrm{ha}^{-1}\right.$ through urea with azolla incorporation @ $16000 \mathrm{~kg} \mathrm{ha}^{-1}$ over $\mathrm{T}_{4}$ with sole application of 
$60 \mathrm{~kg} \mathrm{~N} \mathrm{ha}^{-1}$ through urea to the tune of 6.61 per cent at maturity. Similar results were also reported by Akhter et al., (2002) in rice indicating that the combined application of azolla biomass plus urea-N significantly increased the plant height. However, the present findings are in partial agreement with the result of Paul et al., (2016) who reported that the combined use of organic and chemical sources of plant nutrients in varying proportions resulted better growth of the plants compare to chemical fertilizers alone.

The increase in height with increasing levels of $\mathrm{N}$ be the reason for more plant height in $\mathrm{T}_{4}$ $\left(60 \mathrm{~kg} \mathrm{~N} \mathrm{ha}^{-1}\right.$ through urea) than $\mathrm{T}_{3}(30 \mathrm{~kg} \mathrm{~N}$ $\mathrm{ha}^{-1}$ through urea). The result from the present study confirms the findings of Reddy et al., (1987) and Akanda et al., (1986). Availability of nitrogen throughout the growth stages might be responsible for the better performance of rice (Islam et. al., 2009). Nitrogen in azolla becomes available after its decomposition in the soil. About half of nitrogen was mineralized within 3 weeks of water-logged incubation at $30^{\circ} \mathrm{C}$ and two thirds of nitrogen was released after 6 or 8 weeks of incubation (Moro et. al., 2015). This might be the reason for increased plant height in treatments with azolla incorporation.

\section{Yield of rice $\left(\mathrm{t} \mathrm{ha}{ }^{-1}\right)$}

Grain yield of rice was significantly increased with different level of urea and azola applications under different treatments (Table 2 ). It was found that $T_{6}$ with the application of $60 \mathrm{~kg} \mathrm{~N} \mathrm{ha}{ }^{-1}$ through urea + azolla incorporation @ $16000 \mathrm{~kg} \mathrm{ha}^{-1}$ produced highest grain yield $\left(4.2 \mathrm{t} \mathrm{ha}^{-1}\right)$ which was trailed by $\mathrm{T}_{5}\left(30 \mathrm{~kg} \mathrm{~N}^{-1}\right.$ harough urea + azolla incorporation@16000 kg ha ${ }^{-1}$ ) with $3.77 \mathrm{t} \mathrm{ha}^{-1}$. The per cent increase in grain yield obtained in $\mathrm{T}_{5}$ over $\mathrm{T}_{3}$ (sole application of 30 $\mathrm{kg} \mathrm{N} \mathrm{ha}{ }^{-1}$ through urea) was 17.81 per cent whereas, the per cent increase in $\mathrm{T}_{6}$ over $\mathrm{T}_{4}$ (sole application of $60 \mathrm{~kg} \mathrm{~N} \mathrm{ha}^{-1}$ through urea) was recorded as 17.65. These results confirmed the earlier findings of Singh (1977) and Mahmud et al., (2016) who reported that the incorporation of fresh or dry azolla biomass into the soil always increased grain and straw yield of rice. In the same way, Shanmugasundaram (1990) also found that azolla hybrid along with fertilizer nitrogen increased the grain yield of rice. Significant increase in grain yield of rice was also reported by Kannaiyan (1978) when azolla was used along with $100 \mathrm{~kg} \mathrm{~N} \mathrm{ha}^{-1}$ as USG (Urea super granule).

Table.1 Effect of nitrogen application through urea and azolla on plant height $(\mathrm{cm})$ of rice $($ Oryza sativa $\mathrm{L}$.) at different time intervals

\begin{tabular}{|l|c|c|c|c|}
\hline \multicolumn{1}{|c|}{ Treatments } & 30 DAT & 60 DAT & 90 DAT & At Maturity \\
\hline $\mathrm{T}_{1}$-Control & 46.08 & 72.92 & 98.17 & 98.17 \\
\hline $\mathrm{T}_{2}$-Azolla incorporation @ $16000 \mathrm{~kg} \mathrm{ha}^{-1}$ & 49.75 & 73.83 & 100.67 & 100.67 \\
\hline $\mathrm{T}_{3}-30 \mathrm{~kg} \mathrm{~N} \mathrm{ha}^{-1}$ through urea & 50.75 & 75.50 & 104.33 & 104.33 \\
\hline $\mathrm{T}_{4}-60 \mathrm{~kg} \mathrm{~N} \mathrm{ha}^{-1}$ through urea & 54.50 & 77.83 & 110.83 & 110.83 \\
\hline $\begin{array}{l}\mathrm{T}_{5}-30 \mathrm{~kg} \mathrm{~N} \mathrm{ha}^{-1} \text { through urea+ } \\
\text { Azolla incorporation @ 16000 kg ha }^{-1}\end{array}$ & 58.67 & 80.25 & 114.58 & 114.58 \\
\hline $\mathrm{T}_{6}$-60 kg N ha \\
Azolla incorporation @ $16000 \mathrm{~kg} \mathrm{ha}^{-1}$ & 60.17 & 82.58 & 118.67 & 118.67 \\
\hline $\mathrm{SE}(\mathrm{m}) \pm$ & 2.47 & 2.78 & 4.75 & 4.75 \\
\hline $\mathrm{CD}(\mathrm{P}=0.05)$ & 7.43 & 8.38 & 14.31 & 14.31 \\
\hline
\end{tabular}


Table.2 Effect of nitrogen application through urea and azolla on grain, straw, biological yield ( $\mathrm{t}$ $\mathrm{ha}^{-1}$ ) of rice and harvest index (per cent)

\begin{tabular}{|c|c|c|c|c|}
\hline Treatment & $\begin{array}{l}\text { Grain } \\
\left(\mathrm{t} \mathrm{ha}^{-1}\right)\end{array}$ & $\begin{array}{l}\text { Straw } \\
\left(\mathrm{t} \mathrm{ha}^{-1}\right)\end{array}$ & $\begin{array}{l}\text { Biological } \\
\text { Yield }\left(\mathrm{tha}^{-1}\right)\end{array}$ & $\begin{array}{c}\text { Harvest } \\
\text { Index }(\%)\end{array}$ \\
\hline $\mathrm{T}_{1}$-Control & 2.73 & 5.85 & 8.58 & 31.82 \\
\hline $\mathrm{T}_{2}$-Azolla incorporation @16000 kg ha ${ }^{-1}$ & 2.95 & 6.11 & 9.05 & 32.60 \\
\hline $\mathrm{T}_{3}-30 \mathrm{~kg} \mathrm{~N}^{-1}$ through urea & 3.20 & 6.51 & 9.71 & 32.96 \\
\hline $\mathrm{T}_{4}-60 \mathrm{~kg} \mathrm{~N} \mathrm{ha}^{-1}$ through urea & 3.57 & 7.04 & 10.61 & 33.65 \\
\hline $\begin{array}{l}\mathrm{T}_{5^{-}} 30 \mathrm{~kg} \mathrm{~N} \mathrm{ha}^{-1} \text { through urea }+ \\
\text { Azolla incorporation @ } 16000 \mathrm{~kg} \mathrm{ha}^{-1}\end{array}$ & 3.77 & 7.42 & 11.19 & 33.69 \\
\hline $\begin{array}{l}\mathrm{T}_{6}-60 \mathrm{~kg} \mathrm{~N} \mathrm{ha}^{-1} \text { through urea }+ \\
\text { Azolla incorporation @ } 16000 \mathrm{~kg} \mathrm{ha}^{-1}\end{array}$ & 4.20 & 7.68 & 11.88 & 35.35 \\
\hline $\mathrm{SE}(\mathrm{m}) \pm$ & 0.21 & 0.39 & 0.50 & 2.00 \\
\hline $\mathrm{CD}(\mathrm{P}=0.05)$ & 0.62 & 1.19 & 1.47 & 6.02 \\
\hline
\end{tabular}

In the present investigation also, the higher straw yield $\left(7.68 \mathrm{t} \mathrm{ha}^{-1}\right)$ was recorded in $\mathrm{T}_{6}$ $\left(60 \mathrm{~kg} \mathrm{~N} \mathrm{ha}{ }^{-1}\right.$ through urea + azolla incorporation@16000 $\mathrm{kg} \mathrm{ha}^{-1}$ ) while the minimum straw yield $\left(5.85 \mathrm{t} \mathrm{ha}^{-1}\right)$ was recorded in $\mathrm{T}_{1}$ (control). Again, the results obtained are in agreement with Kannaiyan and Rajeswari (1983) and Islaim et al., (1984) that azolla application increased the yield components of rice. It has been established well that azolla is capable of increasing the grain yields of rice significantly (Lumpkin and Plucknett 1980). The reason for increased yield components and grain yield of rice with azolla incorporated treatments might be due to higher availability of azolla nitrogen to rice plants. When azolla is incorporated into the flooded soil, it undergoes active decomposition and the nitrogen released in ammonical form is readily absorbed by the rice plants. The low yield reported in azolla unincorporated treatments could be due to a lower rate of decomposition and possibly less availability of Azolla-N to rice plants. Moreover, Ito and Watanabe (1985) reported that rice plants absorbed more than 50 per cent of ${ }^{15} \mathrm{~N}$ labelled Azolla-N incorporated at the time of transplanting and when azolla was kept on the surface of water, less than 10 per cent of its $\mathrm{N}$ was available to the rice plants.
Hence, the efficiency of azolla bio-fertilizer could be increased by incorporating it into the rice soil, which avoids losses of nitrogen and higher yield response could be obtained from rice plants. Increased dry matter and grain yields observed in the present study with azolla application have been reported by several workers (Singh, 1977; Talley et al., 1977; Shukla et al., 2016; Rains \& Talley, 1978).

The present investigation demonstrated that application of $60 \mathrm{~kg} \mathrm{~N}^{-1}$ through urea with azolla incorporation @ $16000 \mathrm{~kg} \mathrm{ha}^{-1}\left(\mathrm{~T}_{6}\right)$ was found most effective in increasing grain and straw yield of rice as compared to sole application of azola or nitrogen application through urea. Therefore, the farmers of Meghalaya may be advised to use $60 \mathrm{~kg} \mathrm{~N}$ $\mathrm{ha}^{-1}$ through urea in combination with azolla incorporation @ $16000 \mathrm{~kg} \mathrm{ha}^{-1}$ for getting optimum production of rice in acid soils.

Further, it indicates that farmers can manage around $30 \mathrm{~kg} \mathrm{~N}$ through incorporation of azolla @ $16000 \mathrm{~kg} \mathrm{ha}^{-1}$ in rice crop instead of supplying through nitrogenous fertilizers keeping in view of sustainability of soil health. 


\section{Acknowledgement}

The laboratory facility provided by School of Natural Resource Management, CPGS, CAU, Umiam for carrying out soil and plant analysis for present study is duly acknowledged.

\section{References}

Akanda, M.R.U., Eunus, M., Islam, M.A. and Ali, M.I. (1986). Nitrogen application timing and performance of BR4 transplant aman rice. Bangladesh J. Agric., 11 (1): 39-43.

Akhter, S., Mian, M.H., Kadeer, M.A. and Begum, S.A. (2002). Combination of azolla and urea Nitrogen for satisfactory production of irrigated Boro rice (BRRI Dhan 29). Pakistan J. Agron., 1(4): 127-130.

DES (2015). Annual Progress Report, Directorate of Economic Survey, Govt. of India, pp. 54-129.

Donald, C.M., and Hamblin, J. (1976). The biological yield and harvest index of cereals as agronomic and plant breeding criteria. Advances Agron., 28: 361-405.

FAOSTAT (2014). FAO Global Statistical Yearbook, Food and Agriculture Organization of the United Nations.

Islam, A., Molla, A.L. and Hoque, S. (1984). Azolla and blue green algae as alternative sources of $\mathrm{N}$ for rice and their mineralization in soils of Bangladesh. Ind. J. Agric. Sci., 54: 1056-106.

Islam, M.S., Hasanuzzamanb, M., Rokonuzzamanc, M. K. Nahard (2009). Effect of split application of nitrogen fertilizer on morphophysiological parameters of rice genotypes. Int. J. Plant Prod., 3 (1): 51-62.

Ito, O. and Watanabe, I. (1985). Availability to rice plants of nitrogen fixed by Azolla. Soil Sci. Plant Nutr., 31: 91104.

Kannaiyan, S. (1978). Nitrogen fixation by Azolla. A brief Review. Farm Sci. 5: 19-25.

Kannaiyan, S. and Rajeswari, N. (1983). Comparative effect of fertilizer nitrogen and Azolla biofertilizer on the tiller production of rice. Sci. Cult., 49:2 45-246.

Lumpkin, T. A. and Plucknet, D. L. (1980). Azolla: botany, physiology and use as a green manure. Econ. Bot., 34: 111153.

Mahmud, A.J., Shamsuddoha, A.T.M. and Haque, M.N. (2016). Effect of Organic and Inorganic Fertilizer on the Growth and Yield of Rice (Oryza sativa L.). J. Nat. Sci., 14(2): 45-54.

Moro, B.M., Nuhu, I.R, Ato, E. and Nathanial, B. (2015). Effect of nitrogen rates on the growth and yield of three rice (Oryza sativa L.) varieties in rain-fed lowland in the forest agroecological zone of Ghana. Int. J. Agric. Sci., 5 (7): 878-885.

Paul, S.K., Islam, M.S., Sarkar, M.A.R., Das, K.R. and Islam, S.M.M. (2016). Impact of variety and levels of nitrogen on the growth performance of HYV transplant Aman rice. Progess. Agric., 27: 32-38.

Rains, D. W. and Talley, S. N. (1978). Use of Azolla as a source of nitrogen for temperate zone rice culture. In Proceedings of Second Review Meeting. INPUT, S. Project, Honolulu, Hawaii, pp. 167-172.

Raja, W., Rathaur, P., John, S.A. and Ramteke, P.W. (2012). AzollaAnabaena association and its significance in supportable agriculture. J. Biol. Chem., 40 (1): 1-6.

Shanmugasundaram, R. (1990). Studies on the Sporelings Development from dried 
spore Inoculum of Nitrogen-fixing water fern Azolla Microphylla Kaulfuss, M.Sc. (Ag.) Thesis, Tamil Nadu Agricultural University, Coimbatore, p. 196.

Shukla, S., Meena, R. N., Meena, R., Verma, V.K., Ghilotia, Y. K. and Gaurav (2016). Effects of different organic sources of nutrition on nutrient uptake, yield attributes and economics of Oryza sativa. Bangladesh J. Bot., 45(2): 445-449.
Singh, P. K. (1977). Multiplication and utilization of fern Azolla containing nitrogen-fixing algal symbiont as green manure in rice cultivation. II Riso, 25: 125-137.

Talley, S. N., Talley, B. J. and Rains, D. W. (1977). Nitrogen fixation by Azolla in rice fields. In: Hollander, A. (ed) Oenetic engineering for nitrogen fixation, Plenum, New York, pp. 259281.

\section{How to cite this article:}

Shubham Singh, Sanjay-Swami and Gurjar, G.N. 2018. Effect of Nitrogen Application through Urea and Azolla on Growth and Biological Yield of Rice (Oryza sativa L.) in Acidic Soil of Meghalaya Int.J.Curr.Microbiol.App.Sci. 7(07): 3135-3140.

doi: https://doi.org/10.20546/ijcmas.2018.707.366 